\title{
Market Window Analysis: A Case of Tobacco, Paddy and Big Oinon Farmers in Galewela, Sri Lanka
}

\section{M.T.C.P. Thennakoon and D. A. M. De Silva}

\section{Department of Agribusiness Management, Faculty of Agricultural} Sciences, Sabaragamuwa University of Sri Lanka, P.O.Box. 02, Belihuloya,Sri Lanka.pathirajathennakoon@gmail.com

\begin{abstract}
The study was carried out to determine profitable market existence for tobacco, paddy and big onion cultivations. The research was conducted in Galewela DS division in Matale district. Tobacco, paddy and big onion were considered major cultivating crops in the area during the yala season. The market existence for each crops were evaluated using market window analysis. "Market window" refers to a period of time when the prices received by producers for selected crops were greater than the production costs. Profitability and economic efficiency of each crop was measured in order to identify most suitable crop for the season. Cost of production and budget for each crop was prepared using primary data obtained from the field survey in Galewela DS division. Historical prices were collected from economic centers of Dambulla, Meegoda and Ceylon Tobacco Company. Results revealed that profitable market exists for each crop. There was no market existing for tobacco green leaf before 2009 and the profitable market was emerged for paddy after year 2007. Market for big onion cultivators was profitable during studied time period (2003-2009) but volatile in its pricing pattern. Highest profitability and the economic efficiency were observed for big onion cultivation. Study revealed that most economic crop for yala season was the big onion.
\end{abstract}

Key words: Market window analysis, Cost of production, Profitability, Economic efficiency

\section{Introduction}

Farming is the main livelihood income generating activity in the most parts of the island. Agricultural activities of the North Central Province are diversified with various crop cultivations and entirely depend on the availability of the water. In general, farmers cultivate different crops for the seasons and rice is their principal crop and large extent of paddy cultivation is common in Maha season. Moreover, water scarcity conditions in Yala season make impossible to cultivate paddy in all fields and limited into selected areas. Therefore, 
farmers have to go for alternative crops at Yala season. Majority of farmers in Galawela area cultivate limited amount of paddy and tobacco, and big onion as their Yala crops. Farmers have to select best alternative crop to cultivate in Yala season and the choice of crops directly affect their livelihood.

Selection of crops for the particular season entirely depends on their experience, cultivations trends of the fellow farmers in the area and the assistance given by the agencies. Lack of available information on profitability, suitability, efficiency of crops hinder the progress of farmers and create social problems. Inappropriate or poor record keeping habits mislead them to adapt to various crops for the seasons and which didn't bring any worthwhile returns to them. Limited research in the focused area and poor knowledge sharing with the farmers made serious social issues based on unprofitable crop cultivation. Therefore, current research aimed to bridge the gap and it's relatively worthier to evaluate economic efficiency of the crops for the particular season.

When farmers select a crop as their yala season crop risk associated with each crop should be taken in to account. In fact farmers have to conceder both production risk and market risk which associated with particular crop. Peak harvesting season, market prices for products may not profitable to farmers. Therefore, they have to wait till market price is increased or have to find out alternative markets for the product. In such situation market window analysis provide best solution for the matter.

It is crucial to identify most suitable crop for cultivation. In that case farmers have to conceder their capabilities and the market behavior, especially when there are many alternatives. Because market demand and production cost vary with particular crop type. Individual farmers are not capable enough to identified market economy behavior and production cost for each crop type. The study is to identified market economy behavior and production cost for major cultivating crop in Galewela region. It is better to go for a market window analysis to solve this problem.

Cost of production for particular crop is varying with years. Previous cost of production budget does not imply production cost in this year. Therefore it is better to preparation cost estimation budget for major cultivating crops annually. Earning of high income does not reflect the farmers' profitability. The profitability should be measured related to cost of cultivation. So application of economic data in to profit function and economic efficiency technique better explain about farmers' profitability.

Research Objectives were to identify cost centers and profit associated to common crops in yala season in Galewela DS division, to construct the market 
window analysis for principal yala crops tobacco, paddy and big onion and to determine most economical crop for the yala season.

\section{Concept of Market Window}

In general, economic feasibility depends on the availability of outlets for the produce, the market price, and the cost of production (Colette and Wall, 1978). "Market window" refers to a period of time when the prices received by producers for selected crops are greater than the production costs. The initial step was determining the price advantage of each crop type using the average prices to realize extra profit potential. The next step in the progress was to examine the profit potential by looking at the average price and comparing them to budget of particular crop. This price and cost data were entered in to market-window spreadsheet. This program enabled the agricultural economist to determine the optimal time period to market produce given area, crop, and terminal market.

Market window has been defined in several ways:

- Periods of time when historical average weekly price exceeds estimated unit cost of production (Hinson and Lanclos, 1988)

- The period of time for a given crop and market during which prices are generally at or above the producer's break-even or "at market" cost (Zwingli, et al., 1989)

- The period when expected market prices are greater than the production cost for a long enough period (at least two months) to justify a reasonable production scale (Rourke, 1984)

- A particular period of time during which a commodity can be sold at a profit in an existing market (Venturella et al., 1988)

A profitable market window shows a positive difference between revenues and costs. The market window is created by collecting and plotting historical prices and subtracting pre-harvest, harvest, fixed, and transportation costs. These budgets represent factor cost and return for economics. Production cost budget were estimated by calculating factor costs and organizing a budget into pre harvest, harvest transportation costs. Cost calculation was done in per acre basis. All calculations which related to market window analysis have been done in terms of estimated cost of production. Therefore in market window graphics production costs remain constant.

\section{Methodology}

Both primary and secondary data were use for the market window analysis. Primary data was collected using field survey in Galewela DS division in Mathale district. Secondary data was extracted from the published sources of the island wide Dedicated Economic Centers, Ceylon Tobacco Company and Department of Agriculture. 
Data collection was done using purposive sampling technique. In Galewela area, 7200 families cultivated paddy around 5496 acres in yala season. There were about 540 big onion growers and their cultivated land extend was about 625 acres in 2009 yala season. (Dept. of Agriculture, 2009). Total tobacco cultivated land extent was 1720 ha in Galewela area.

Primary data was collected from the selected farmers of the each crop type and the sample size was thirty farmers for each. Interviewer administered questionnaire was prepared for the data collection. Agricultural production is heavily depends on labor and labor cost calculation was utilized both family and hired labor. A man day was considered as eight hours and cost for a unit man day calculated as Rs 500.00/day and for female Rs 350.00/day (Dept. of Agriculture, 2009).

In general farmers used their own seeds for paddy and big onion cultivations and the market average prices for particular seed variety was taken for costing purposes. Even though farmers used their own machineries cost was calculate related to the established rates for the particular operation in the season due to inadequacy of data such as depletion of machinery, varied rent rates, fluctuation of the rates, etc.

Two types of communities were involving in tobacco cultivation in Galewela area such as Cured Leaf Suppliers (CLS) and Barn Owners (BO). The farmers of the Barn Owners community, who sell their green leaf harvest to the barn owners, were referred as "sub growers". Curing of tobacco leaves and selling them in to CTC is done by barn owners. In this research cost estimation data was collected from sub growers for green leaf production.

Prices of agro chemicals and fertilizer were extracted from the CTC material prices list issued for 2009 Yala crop season for the production cost calculation purposes. Further, costing of machinery operations were carried out using established rates for particular practices by barn owner association (Yala Bala Mandalaya). This is due to inadequate of data for machinery depreciation, seasonal rates, fluctuations, locational matters, etc.

\section{Assumptions underline the process}

- Pricing data used in the analysis was of a historical nature and future prices may deviate from those prices collected in 2003-2009

- During the growing season, production cost per box remains constant.

- Practices should not be considered recommendations by the Department of Agriculture and Ceylon Tobacco Company but represent production procedures considered typical for particular crop and area.

- Some of the cost and practices may not be applicable or used during every production year. 
- Cultural practices and costs to produce particular crop will vary by grower and region, and can be significant.

- Extra costs may be involved for moving equipment between fields, expenses for meals during working but are not included in study.

\section{Location}

Data collection for preparation of cost estimation budget was done in several regions in Galewela DS division. Majority of tobacco farmers were based in Kudawewa and Galapamula areas. Big onion cultivation was highly carried out in Makulugolla and Karabayaya areas. Thalakiriyagama, Yatigalpoththa and Puwakpitiya were famous for paddy cultivation and cultivation extent was large compared to other crops. Most big onion growers sold their harvest to Dambulla Economic Center.

\section{Data and Data Collection Tools}

The research determines the profitability for farmers of marketing Tobacco, Paddy and Big onion Galewela DS division in Mathale district. The primary data for the market-window analysis was derived from the data obtained from the economic centers and Ceylon Tobacco Company. For tobacco, prices issued for Yala crop - 2009 was taken in to account.

Cost of production Budgets were estimated for each crop. The economic data was entered in to market window analysis and the profitability of each crop was estimated related to prices of economic centers located in island wild for big onion and paddy and prices of Ceylon Tobacco Company for tobacco.

\section{Market Window Analysis}

The profitability of each crop was illustrated by market-window graphics. Market-window was generated using an analysis platform developed by Kalo (1998). The profitability estimated were calculated by posting historical prices in a Microsoft Excel spreadsheet and subtracting corresponding units costs for production and transportation. The prices were also used directly in cost/profit graphing and analyzed by averaging each year over the entire time span to get one average for each year from 2003-2009.

Cost of production data was taken from a field survey in Galewela DS division for each crop. Cost estimation was used for the comparison purposes with market prices and farm-gate prices as base year prices for cost of production. Economic analysis of the market - window can reveal whether market opportunities exist for tobacco, paddy and big onion.

Further, the market profitability evaluation was completed and estimated cost of production budget in 2009 field survey was used as base year cost estimation. The results of market window analysis, the graphical illustration of production 
cost line remains constant with particular period of time. Profitability of cultivation was measured using profit function. Economic efficiency for each crop was calculated.

\section{Theoretical Modeling of Profit Function}

Debertin (1986) profit function was used for the calculation of profits. Farmer's profit (net revenue) is equal to total revenue (TR) minus total cost (TC).

Hence:

$\Pi=$ TR - TC

Where:

$\mathbf{T R}=\mathbf{P} * \mathbf{Q o}$

$\mathbf{T C}=\mathrm{Vi}^{*} \mathbf{X i}$

Inserting the values of TR and TC, in equation 1 , results the following equation $\Pi=\mathbf{f}(\mathbf{P}, \mathbf{C}, \mathbf{Q})=\mathbf{P Q o}-\mathrm{Vi} \mathbf{X i}$

Where:

$\boldsymbol{\Pi}=$ Profit (Net Revenue); $\mathbf{P}=$ Output price at wholesale level (Rs $/ \mathrm{kg}) ; \mathbf{C}=$ Cost per unit produced $(\mathrm{Rs} / \mathrm{Kg}) ; \mathbf{Q}=$ Total production $(\mathrm{kg}) ; \mathbf{T C}=$ Total cost of production (Rs/acre); $\mathbf{V i}=$ Input prices; $\mathrm{i}=1.2 .3 \ldots \mathrm{n}$

\section{Net Revenue $=$ TR - TC}

\section{Analytical Techniques of economical efficiency}

The economic efficiency (ei) for the particular crop is mathematically expressed as

AGMi $=$ ATRi - AVCi

ANFIi $=$ AGMi - AFCi

Where AGMi is the average gross margin of crop,

ATR $i$ is the average total revenue of crop,

$\mathrm{AVCi}$ is the average variable cost of crop production,

ANFIi is the average net farm income of cultivation of crop and

AFCi is the average fixed cost

ATCi is the Average total cost

The economic efficiency (ei) for the particular crop is mathematically expressed as

$$
\text { ei }=\text { ANFIi } / \text { ATCi }
$$

When ei $>0$, the production of the crop is economically efficient When ei $<0$, the crop production is economically inefficient

But when ei $=0$, the production of the crop is said to be at the breakeven point. (Omonona-2009).

\section{Sample profile}

Sample profile of the study and the socio-economics of the respondents were listed in table 1 . 
Table 1 - Sample profile of farmers

\begin{tabular}{|c|c|c|c|}
\hline & \multicolumn{3}{|c|}{ Percentage } \\
\hline & Paddy & Tobacco & Big onion \\
\hline \multicolumn{4}{|c|}{ Education level } \\
\hline Primary & 74 & 80 & 71 \\
\hline Secondary & 23 & 20 & 29 \\
\hline Tertiary & 3 & 0 & \\
\hline \multicolumn{4}{|c|}{ Age distribution } \\
\hline$<30$ & 14 & 17 & 21 \\
\hline $30-40$ & 21 & 10 & 25 \\
\hline $40-50$ & 21 & 39 & 36 \\
\hline $50-60$ & 30 & 17 & 11 \\
\hline$>60$ & 14 & 17 & 7 \\
\hline \multicolumn{4}{|c|}{ Cultivated extent/ac } \\
\hline$<0.5$ & 46 & 53 & 40 \\
\hline $1.00-1.5$ & 42 & 40 & 50 \\
\hline$>1.5$ & 12 & 7 & 10 \\
\hline
\end{tabular}

Source: Field survey, 2009

Table 1 describes the education levels and age distribution of the respondent farmers. According to the results, majority of farmers were completed only primary education. Especially, for the tobacco cultivation, $80 \%$ farmers were lies in low level of formal education or completed only primary education.

Age distribution of the farmers in the sample, $30 \%$ of paddy farmers belong to the age group $50-60 \mathrm{yrs}$. Comparatively small number of farmers belongs to the age category $>60 \&<30$ and results highlighted that youth involvement in farming was low.

According to the table 1 majority of paddy farmers have lands less than 0.5 / ac. In big onion farmers, $50 \%$ of farmers' have between $1.0 / \mathrm{Ac}-1.5 / \mathrm{Ac}$ land extent. Limited numbers of Farmers have land extent greater than 1.5/Ac.

\section{Results and Discussion}

Background of tobacco, paddy and big onion cultivators were described in this section that observed in the study. According to the results of market window analysis, profitability of big onion cultivation and economic efficiency of big onion cultivation is higher than other cultivated crops. Profitable market exists for all studied crops in 2009. But there can be identified a wide gap between farm gate price and market prices of big onion and paddy. 
Two categories of tobacco farmer groups can be identified in Galewela area such as Barn owners and sub growers. There, barn owners can be considered as powerful and resource rich community engaged in tobacco cultivation. They maintain tobacco seedling nurseries, provide materials and credits for tobacco sub growers and finally purchase green leaf harvest from sub grower owners. Tobacco leaf curing is done by barn owners. Risk associated with tobacco cultivation and leaf curing was beard by the barn owners. Sub growers were the community that cultivated tobacco plants in their owned fields or rented or hired fields. They purchase seedling from barn owners. Agrochemicals, credit facilities for hired labors are provided to them by barn owners. Finally those expenses are deducted from their green leaf harvest by the barn owners. Table 2 shows number of registered barn owners and sub grower of CTC in study area.

Table 2: Tobacco leaf supplier to CTC

\begin{tabular}{ccc}
\hline \multirow{2}{*}{ Year } & \multicolumn{2}{c}{ Number of registered farmers } \\
\cline { 2 - 3 } 1985 & Barn-owners & Sub-growers \\
1986 & 3,712 & 27,974 \\
1987 & 3,600 & 28,800 \\
1988 & 3,420 & 23,840 \\
1989 & 3,612 & 27,896 \\
1990 & 3,410 & 27,280 \\
1991 & 3,210 & 25,680 \\
1992 & 4,150 & 29,050 \\
1993 & 5,240 & 36,680 \\
1994 & 5,475 & 32,850 \\
1995 & 6,702 & 33,510 \\
1996 & 6,336 & 31,680 \\
1997 & 7,420 & 29,680 \\
1998 & 8,743 & 34,792 \\
1999 & 3,518 & 21,108 \\
\hline
\end{tabular}

Source: Ceylon Tobacco Company (2009)

\section{Background of Paddy Farmers}

In general, yala paddy cultivation in Galewela area has been limited mostly for the household consumption of the farm families. Moreover, in many cases farmers use both family labor and exchange labor for cultivation than the hired labor. Comparatively low number of farmers cultivate paddy in Yala 
season than the Maha season. Paddy cultivation fields also limited with water availability. Most of the paddy fields were located at the close proximity to the water reservoirs. Surface irrigation method is commonly practiced as irrigation method. Three and half month duration paddy verities such as BG 352, BG 356, and BG 34-8 were grown in Yala season. Short duration paddy verities were highly suseptible for water stress and extreme weather conditions. Generally, harvesting was carried out using combine harvesters. Figure 1 present the fluctuation of market price and farm-gate price of rice. April and December, festival season leads to increase of both farm-gate price and market price and was visible in the results too. But the price difference between farm-gate price and market price of rice was quiet high based on graphical analysis.

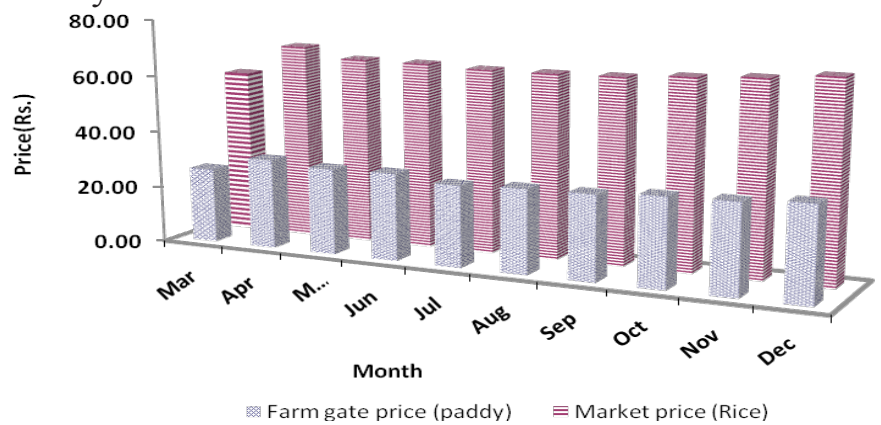

Figure 1: Farm gate prices \& market prices of paddy in 2008

\section{Background of Onion Farmers}

Two kinds of big onion growers can be identified in Galewela area as farmers who have their own cultivated land and farmers who cultivated in rented/ hired fields. These tenant farmers have established cottages in their fields and live throughout the cropping season. These farmers use surface irrigation system for irrigation and usually they used diesel or kerosene water pump for pumping purposes in irrigation. Here tenant farmers keep minimum contacts with the Department of Agriculture.

Farmer organizations were not properly organized and functioning. Existing organizations remains in order to get fertilizer subsidies for their farming. These farmer organizations do not have proper link and develop communication system with the Department of Agriculture in order to get extension services for the particular farming community in the region. Their irrigation systems and water management activities were poor and unorganized and conflicts during dry period were common.

Extension programs were provided by the Department of Agriculture to the onion growers. Farmers were organized in regional levels and communicate with the Department of Agriculture for the purposed of receiving extension 
advice and other benefit packages but their commitment was poor in groups. Services that are taken by the particular farming community depend on their requirements and strength.

The potential market window for tobacco, paddy and big onion were identified in this section. Most economical crop for yala season was identified using achieved results trough tobacco, paddy and big onion. In case of tobacco the economic profitability is discussed in terms of green leaf and cured leaf. In order to producer profitability related to the market both farm-gate price and market price was taken in to account. The discussion of the results is accompanied by corresponding figure for each crop.

Highest net revenue was obtained from big onion cultivation (Rs. 142,090.00/ ac). The second highest net revenue Rs. 54,161.00/ac was recorded from tobacco green leaf production. The lowest net revenue Rs. 20,156.00/ac was obtained from paddy cultivation. Results imply that big onion was the most profitable crop for the season (Figure 2).

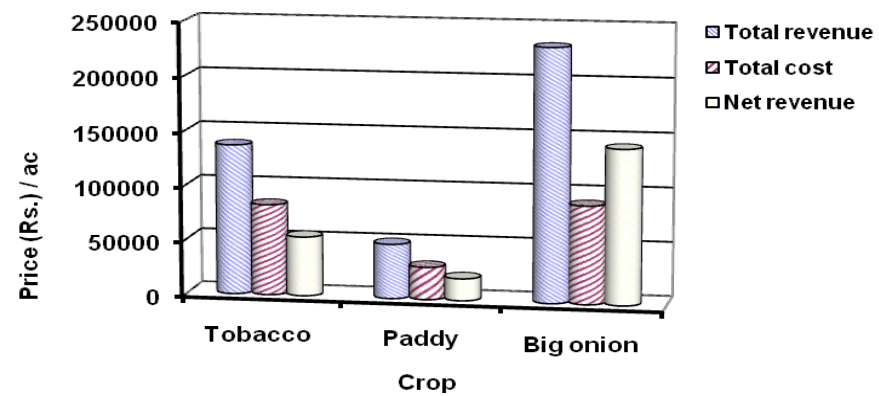

Figure 2: Total revenue, total cost and net revenue of tobacco, paddy and big onion

The economic efficiency of each crop was greater than $0 />0$, means that each and every crop that the study was carried out was economically efficient. Highest economic efficient crop was recorded for onion cultivation. Economic efficiency of tobacco was less related to paddy cultivation even though profitability was higher than profitability of paddy cultivation (Figure 3).

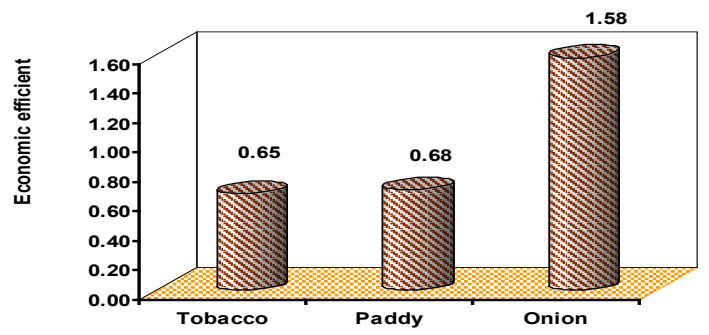

Figure 3: Economic efficiency of cultivations 
Graphical expression illustrates the relationship between farm-gate prices and cost of production (Figure 4). There can be identified the fluctuation of farmgate prices with the time. After the year 2006, farm gate prices of paddy have been increased sharply. Market was at the breakeven point at year 2007.

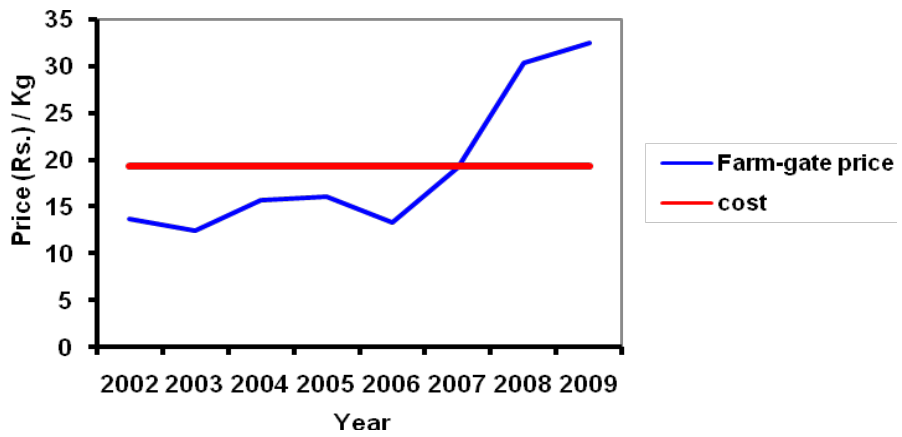

Figure 4: Paddy farm gate-price variation with year

Market is profitable for paddy cultivators in 2009. Since year 2006 fertilizer subsidies were given by the government. Therefore government attention for agricultural sector may lead to exceed farm-gate prices than estimated cost of production.

According to Figure 5 fluctuation of farm gate prices and market prices can be observed with the time. Both market prices and farm gate prices have been increased in April and December. Remarkable declining of paddy prices show in March. And in August also farm-gate price of paddy is quite low. Fluctuation of farm-gate prices can be observed throughout the year. Price fluctuations were mainly due to the seasonal effects based on harvesting time and demand based on national festive season.

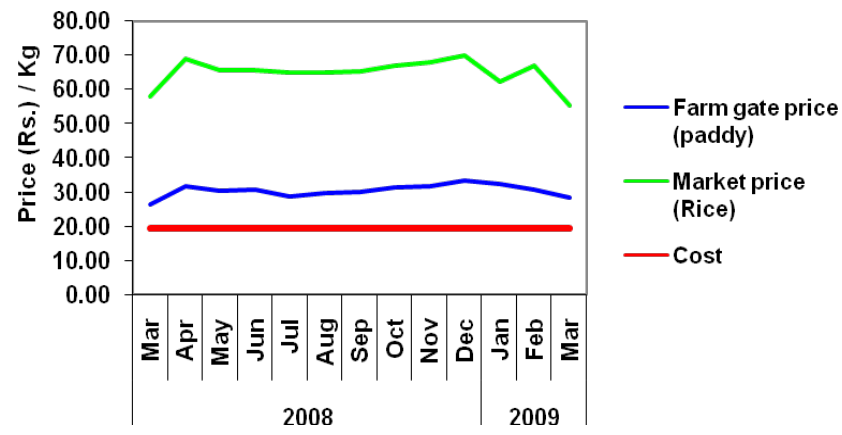

Figure 5: Paddy farm gate, production cost and market price variation with time

Price increase in December and April may due to festive season such as New Year and Christmas. In Sri Lanka highest paddy harvest is taken in maha season. 
Declining of prices at March may due to maha paddy harvest. In August and September is the period for yala paddy harvest. Market prices were low during the harvesting time and tend to change with the time. However, throughout the year paddy market was exist for producer and market is economical. According to the graphical analysis there was a big gap between farm-gate price and market prices of paddy (Figure 6). Cost of paddy processing and milling was claim for that cost (gap between farm gate and market). Paddy processing and milling incur costs and transportation cost was high. During the festive seasons in April and December profitability of producers was high.

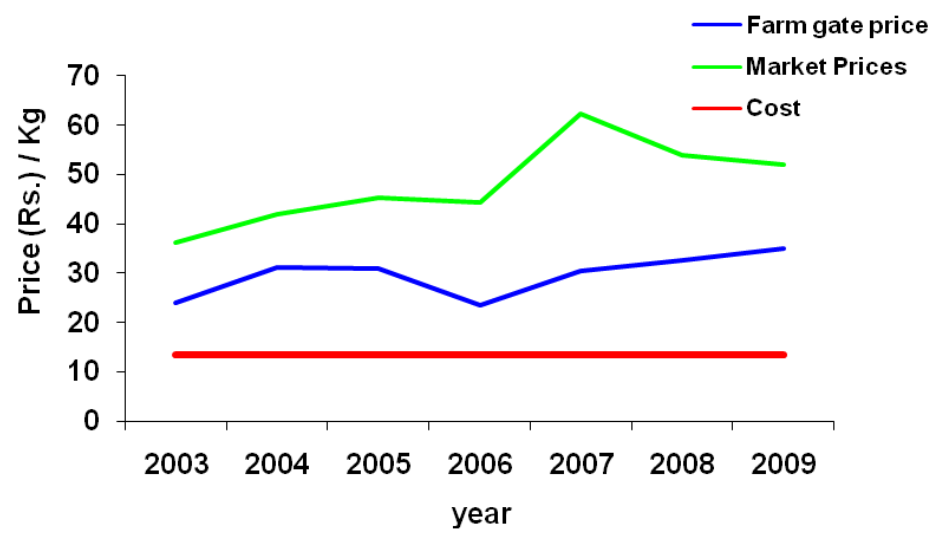

Figure 6: Farm gate price, market price and cost variation for big onion

Fluctuation of farmer-gate prices can be observed with years. Lowest farmgate price for paddy can be observed during year 2006. After the year 2006 farm-gate prices of big onion was increased gradually. Graphical analysis is shown that market is profitable for big onion growers in 2009. Findings were highlighted that economically worth of cultivating big onion during 2009. Comparison of farm-gate price with market price of the big onion shows a wide gap (Figure 6). Wide gap explains that the large portion of the profitability was taken by the intermediaries, between big onion producers and final consumers. Fluctuation of farm-gate and market price of big onion have similar pattern from 2003 to 2007. There should be a relationship between market price and farm-gate price of big onion.

Production cost of green leaf was Rs. 12.40/Kg in 2009 (Figure 7). Farmers obtain highest income respected to previous years. Figure 7 shows that previous prices of previous years for green leaf were below than its production cost. This is due to the changes of rates for man day and rate differences based on gender differences (unit of male man day was calculated as Rs. 400.00 and female day was Rs. 300.00 in cost estimation). In this year it is estimated 
as Rs. 500.00 for man and Rs. 350.00 for female. Green leaf production cost of previous year was Rs.11.17. Prices of green leaf have been increased drastically with time and especially from 2003 to 2008. In 2009, green leaf price has been increased from remarkable amount. According to graphical analysis market exist for tobacco growers only in 2009 .

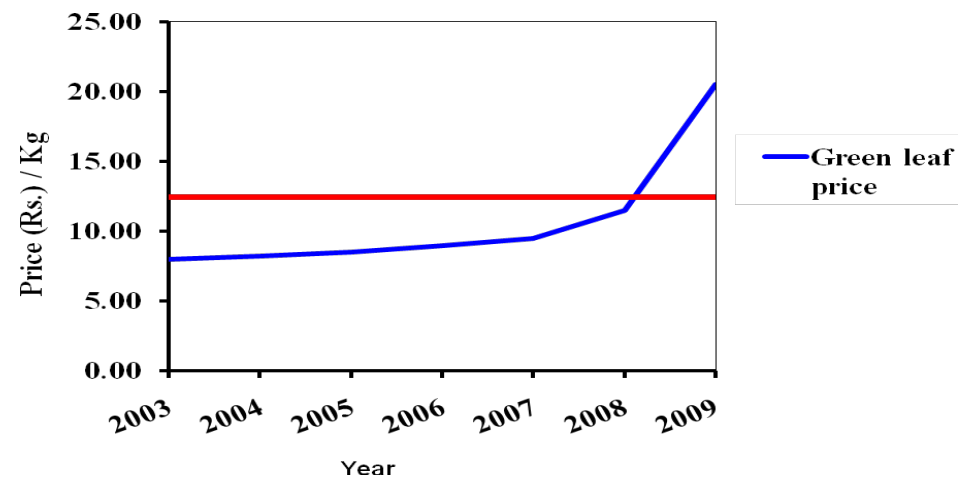

Figure 7: Tobacco green leaf price variation with production cost

\section{Conclusion}

Research was carried out to find out the profitable market existence for the common crops in yala season in. Results of the market window analysis show that highest profit was obtained from big onion cultivation and second largest profit was taken from tobacco cultivation. The lowest profit was taken from paddy cultivation. According to the results the most economical crop was big onion for the yala season. Big onion cultivation was economically efficient compared to other crops. Economic efficiency of tobacco was less compared to paddy. Therefore cultivating tobacco is not economically efficient, even though its profit is higher than profit gained from paddy production.

The study identified two kinds of risk factors such as price risk and production risk. The market window analysis implies that production cost risk may greater than price risk in 2009 for each crop. In the case of tobacco green leaf price risk is higher before 2008. Market is more profitable for paddy and big onion cultivators in 2009.In festival seasons market is profitable for paddy growers and in harvesting seasons farmers can earn less profit. Profitable market for tobacco green leaf can only be observed in 2009. Prices of green leaf showed positive increasing pattern with the time. Research findings have proved the profitable market existence of selected crops in selected farming area of the region. Results of the study provide guiding tools to the policy makers in agriculture sector. Crop selection for the particular season should base on scientific evidence and it should be based on applied research findings. Market window analysis will help to select crops for the particular region as well as for the specified season. Further, results can direct farmers to select crops with profitable market existence. 


\section{References}

Colette, W.A. and Wall, G.B. (1978). Evaluating Vegetable Production for MarketWindows as an Alternative for Limited Resource Farmer, Southern Journal of Agricultural Economics, 10, pp. 189-193.

Ceylon Tobacco Company. (2009). Price list for the agricultural inputs, Ceylon Tobacco Company, Colombo, Sri Lanka

Debertin, David L. (1986). Agricultural production economics, Macmillan Publishing company, New York.

Department of Agriculture. (2009). Annual report, Department of Agriculture, Kandy, Sri Lanka

Hinson, R. and Lanclos, K. (1988). Wholesale Market Opportunitiesfor Fresh Commercial Vegetables,A.E.A. Information Series No. 65-67. Louisiana State University: Department of Agricultural Economics.

Kalo, A. (1998). Virginia Farmers' Markets: Production Budgets, and Market Window Analysia. Excel Spreadsheet. Blacksburg: Virginia Tech.

Omonona, B.T., (2009). Cost and return to contract seed production in Nigeria: Evidance from Osun state, Central European Agriculture journal, Volume 7, No. 3 (475-478).University of Ibadan, Ibadan

O’Rourke, A.D. (1984). Market Opportunities for Minor Washington Fruits and Vegetables, Research Bulletin XB 0946. Washington State University: Agricultural Research Center.

Venturella, J. G., Rathwell, P.J., Bauer, L.L. and Caines, R. (1988). Potential Markt Windows for Selected Vegetable Crops in South Carolina, Bulletin 663. Clemson University: South Carolina Agricultural Experiment Station.

Zwingli, M.E.J.L., Adrian, Hardy, W, E. and Free, W.J. (1989). Wholesale Market Potential for Fresh Vegetables Grown in North Alabama, Bulletin 586. Auburn University: Alabama Agricultural Experiment Station. 